\title{
ZEMĚTŘESENÍ V HOSTĚRADICÍCH V ČERVNU 2014
}

\author{
Earthquakes in Hostěradice in June 2014
}

\author{
Jana Pazdírková', Jan Zedník², Ivan Prachař³, Hana Krumlová', Pavel Zacherle \\ 1 Ústav fyziky Země, PřF MU, Tvrdého 12,602 00 Brno; e-mail:jana.pazdirkova@ipe.muni.cz \\ ${ }^{2}$ Geofyzikální ústav AV ČR, v. v. i., Bočni II/1401, 14131 Praha 4 \\ ${ }^{3}$ Náchodská 955, 193 00, Praha 9
}

(34-11 Znojmo)

Key words: felt earthquake, seismicity, macroseismic intensity, historical earthquakes, southeastern margin of the Bohemian Massif

\begin{abstract}
Southern Moravia - a southeastern part of the Czech Republic at the contact of the Bohemian Massif and the Carpathian Foredeep - is one of the regions with the lowest seismic activity in the Czech Republic. Reports on historical earthquakes in this area are sporadic and poorly evidenced, many of the messages are in fact observations of earthquakes originating mainly in Austria. Instrumental seismic monitoring in southern Moravia commenced in 1995. Thereafter only three local earthquakes were observed - magnitude 2.5 event near Hostěradice in 2000, perhaps induced event near Uhřice in 2003 with magnitude of 0.7 and magnitude 1.4 earthquake near Božice in 2006.

A sequence of four weak earthquakes in June 2014 is only the fourth occurrence of earthquakes in southern Moravia since the beginning of instrumental measurements. Events originated near Hosterradice (SE margin of the Bohemian Massif), $40 \mathrm{~km}$ southwest of Brno. The strongest event reaching local magnitude of 2.0 occurred on June 1, 2014 at 00:43 UTC. It was felt by people close to the epicentre with a macroseismic intensity 4 European Macroseismic Scale EMS-98. A temporary seismic station was immediately installed in the epicentral area. The station recorded two of four shocks and helped to confirm a focus position of the sequence: $48.95^{\circ} \mathrm{N} 16.24^{\circ} \mathrm{E}$, depth $3 \mathrm{~km}$.

In 2014 a review of historical earthquakes in this region was conducted using new catalogues of historical earthquakes in neighboring countries in order to avoid confusion between local and regional phenomena. Some new information sources were found. In any case, historical earthquakes in this region are very rare and most of them are poorly substantiated.
\end{abstract}

Úvod

V první polovině června 2014 zaregistrovaly seismické stanice Ústavu fyziky Země PřF Masarykovy univerzity (ÚFZ) sérii čtyř zemětřesení na j. Moravě s ohniskem u obce Hostěradice. Magnitudo nejsilnějšího otřesu z 1. 6. 2014 bylo 2,0. Toto zemětřesení bylo dokonce pocítěno obyvateli v nejbližším okolí epicentra.

Zemětřesení s ohniskem na jižní Moravě se vyskytují výjimečně. O lokálních historických zemětřeseních máme jen několik zpráv. Od roku 1995 je oblast sledována seismickou stanicí Moravský Krumlov (KRUC), od roku 2013 další stanice monitorují případnou seismickou aktivitu v okolí jaderné elektrárny Dukovany. I citlivé př́stroje však dosud zaregistrovaly pouze několik velmi slabých otřesů.

\section{Série otřesů z června 2014}

$\mathrm{V}$ neděli 1. 6. 2014 v 00.43 hod. UTC (Coordinated Universal Time, tj.
02.43 hod. stř̌edoevropského letního času - SELČ) zaregistrovaly seismologické stanice ve střední Evropě zemětřesení s ohniskem západně od obce Hostěradice (obr. 1). Souřadnice epicentra jsou $48,95^{\circ}$ severní zeměpisné šířky

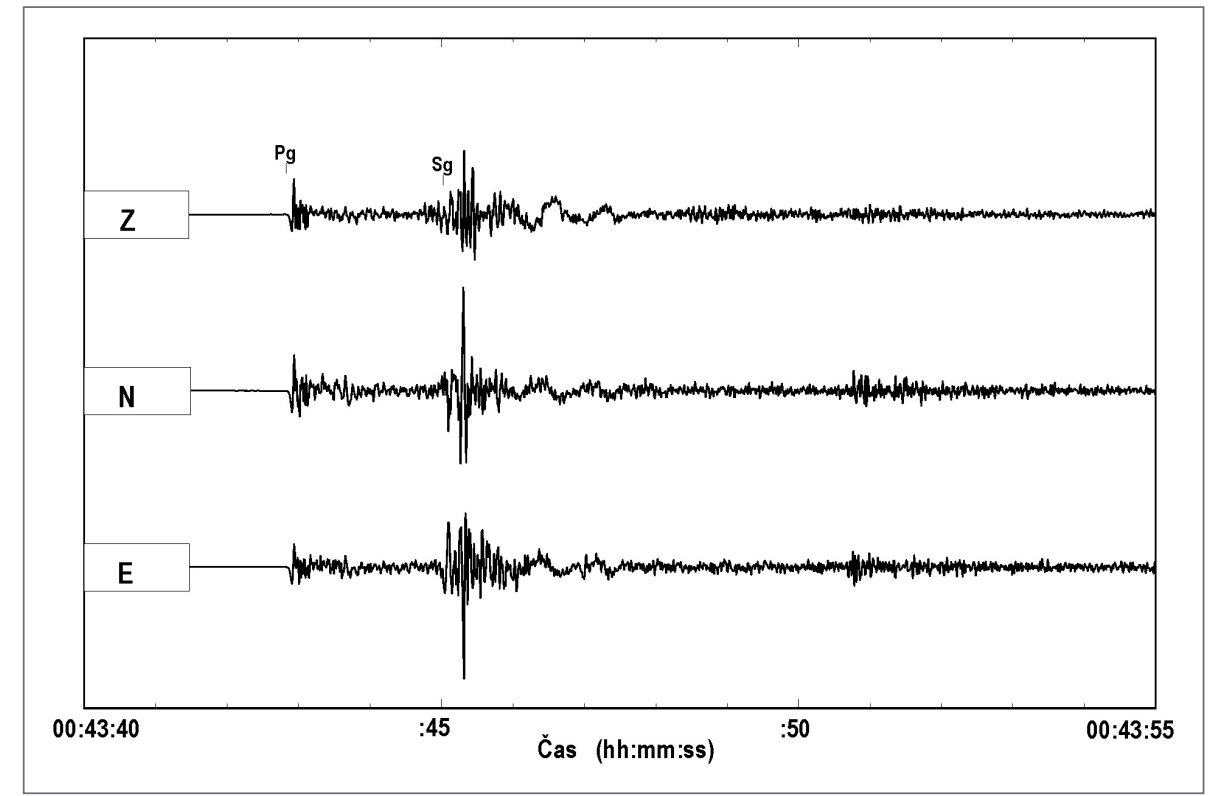

Obr. 1: Zemětřesení zaregistrované 1. 6. 2014 v 00.43 hod. UTC (Coordinated Universal Time, tj. 02.43 hodin středoevropského letního času - SELČ) s epicentrem u Hostěradic, magnitudo 2,0. Ukázka signálu na nejbližší stanici Moravský Krumlov (KRUC), vzdálené 17 km od epicentra. Fig. 1: Earthquake recorded on June 1, 2014 at 00:43 UTC (02:43 Central European Summer Time) with epicentre near Hostěradice (Southern Moravia), local magnitude 2.0. Seismogram from the nearest station Moravský Krumlov (KRUC), epicentral distance $17 \mathrm{~km}$. 
a $16,24^{\circ}$ východní zeměpisné délky, hloubka ohniska je $3 \mathrm{~km}$ a magnitudo 2,0. Otřes byl velmi dobře zaznamenán množstvím seismických stanic až do vzdálenosti asi 200 km. Týž den, 1. 6. 2014 v 7.32 hod. UTC zaregistrovaly seismické stanice další zemětřesení ze stejného ohniska. Otřes byl slabší, s magnitudem 0,6.

Následující den byla jižně od obce Hostěradice nainstalována dočasná seismická stanice provozovaná ÚFZ s kontinuálním záznamem dat pro registraci případných dotřesů. Místo bylo vybráno tak, aby stanice vhodně doplňovala geometrii sítě stávajících stanic kvůli upřesnění polohy ohniska. Dočasná stanice byla $\mathrm{v}$ provozu téměr měsíc a během té doby zaregistrovala další dvě velmi slabá zemětřesení. Nejslabší otřes z 16. 6. 2014 v 7.51 hod. UTC s magnitudem -0,9 byl zaznamenán pouze dočasnou stanicí u Hostěradic a stanicí KRUC. Jev ze 17. 6. 2014 v 14.25 hod. UTC s magnitudem - 0,3 byl zaregistrován celkem pěti stanicemi ve vzdálenosti od 4 do $50 \mathrm{~km}$. Detailní srovnávací analýza seismického záznamu dvou dotřesů zaznamenaných dočasnou stanicí a záznamu všech čtyř jevů na stanici KRUC i dalších blízkých stanicích potvrdila, že všechny otřesy pocházejí ze stejného nebo velmi blízkého ohniska. Lokalizace jevů s přispěním dočasné stanice potvrdila jak polohu epicentra, tak i malou hloubku ohniska.

Ohniska zemětřesení z června 2014 leží v oblasti kontaktu Českého masivu a karpatské předhlubně při jz. ukončení boskovické brázdy. Zlomový systém ssv.-jjz. směru doprovázející jv. okraj Českého masivu, do něhož náleží také východní okrajový zlom boskovické brázdy, diendorfský zlom a weitzendorfský zlom, je segmentován příčnými zlomy. Jednoznačná korelace červnových zemětřesení s konkrétním zlomem není na základě současných poznatků možná.

\section{Makroseismická pozorování}

Navzdory relativně nízkému magnitudu a nepř́liš příznivé noční hodině ( 2.43 hod. SELČ) bylo zemětřesení z 1. 6. 2014 pozorováno obyvateli nejbližších obcí. První zpráva o pocítění byla zjištěna telefonickým dotazem na obecní úrad v Hostěradicích. Na okolní obecní úřady byla poté rozeslána e-mailová žádost o rozšírení informace o zemětřesení mezi občany s prosbou o vyplnění makroseismického dotazníku na internetové stránce Geofyzikálního ústavu AV ČR. Dotazník vyplnilo čtrnáct lidí, přičemž většina $\mathrm{z}$ nich udávala, že zemětřesení pozorovala také řada dalších osob. Respondenti z obcí Hostěradice, Morašice a Skalice byli probuzeni ze spánku a pocítili slabé nebo silné zachvění. Většinou byli vyděšeni zejména silnou ranou a duněním a vyběhli z domu podívat se, co se stalo. Lehký nábytek se zatřásl, okna drnčela, nádobí cinkalo, zvířata byla neklidná. Pozorování byla ohodnocena stupněm 4 makroseismické stupnice EMS-98.

\section{Seismicita oblasti}

Z historických pramenů máme jen velmi málo zpráv o lokálních zemětřeseních z jižní Moravy, velká část $\mathrm{z}$ nich je navíc špatně doložená. $\mathrm{V}$ různých zdrojích jsou zemětřesení občas zmíněna, ale většinou se jedná o pozorování vzdálených otřesů s ohnisky v Rakousku nebo na Slovensku.

Jednou z takových zmínek je např. záznam z Kroniky města Znojma (Vrbka 1902) o zemětřesení z roku 1581: "21. července nastalé zemétřesení nahnalo Znojemským velkýstrach“. Tento jev však neměl ohnisko u Znojma, ale u rakouského Schwadorfu (Hammerl - Lenhardt 2013). Podobně Jaroš a Malý (2001) dokladují zemětřesením u Ivančic v roce 1963 současnou aktivitu boskovické brázdy, ale toto zemětřesení nemělo ohnisko na Ivančicku, ale v Rakousku poblíž Wiener Neustadtu (Hammer - Lenhardt 2013). Pozorování vzdálených zemětřesení jsou poměrně častá, např. 20. 9. 2013 a 2. 10. 2013 byla lidmi na jižní Moravě (např. Znojmo, Miroslav, Šatov, Šaldorf, Mramotice, Žerůtky, Rajhrad, Zbýšov, Brno) zřetelně pocítěna zemětřesení s ohniskem u rakouského Ebreichsdorfu jižně od Vídně. Při hodnocení historických zemětřesení je proto nutná velká opatrnost a korelace s katalogy okolních zemí, aby byla vyloučena záměna lokálního a vzdáleného zemětřesení.

V roce 2014 byla provedena revize všech zpráv o historických zemětřeseních na jižní Moravě. Dosud známé záznamy o zemětřeseních byly porovnány s novými zahraničními katalogy a byly rovněž dohledány nové podklady. K některým zemětřesením se však zdrojové informace dosud nepodařilo najít, problematická je interpretace zejména starších záznamů. Až do 18. století zatím nemáme z popisovaného prostoru žádné zprávy o lokálních zemětřeseních.

Nejstarší zmínkou o místním zemětřesení na jižní Moravě může být záznam, který uvádí Schram (1901) k roku 1751: „13. července mezi 7 a 8 hod. bylo zemétřesení a totéž podivně trvalo v Židlochovicích až po dobu tř́ Otčenášù. “ Tento jev není popsán v žádném regionálním katalogu. Dosud se nepodařilo dohledat zdroj, ze kterého Schram čerpal, není tedy vyloučena chyba, at už v čase nebo $v$ místě.

Nedostatečně doložené jsou také dva jevy s možným ohniskem u Brumovic v. od Hustopečí z 2. 12. 1874 a 18. 1. 1886. Oba jevy uvádí např. Kárník et al. (1958) nebo Michal (1959), ale ani v tomto př́ípadě není jasný zdroj a tedy ani správnost času a místa.

Dobře je dokladováno zemětřesení v Lesonicích sz. od Moravských Budějovic z roku 1907 ve zprávě referenta Rzehaka (1909) rakouské zemětřesné komisi: „25. listopadu 1907, v14h.15m. odpoledne slyšeli v Lesonicích, severozápadně od Moravských Budějovic, ve směru na jihovýchod, velmi silnou detonaci, podobnou výstřelu $z$ děla. Po této detonaci následoval 10 minut trvajíci temný podzemní rachot. Jev byl vnímán mnoha obyvateli obce."

Sporné jsou zprávy o zemětřesení ve Znojmě 26.1 . 1927, v Brně 15. 2. 1946 nebo v Dalešicích 5. 2. 1949 (Kárník et al. 1958; Michal 1959), zdrojové informace o těchto jevech se dosud nepodařilo dohledat.

Zemětřesení jsou velmi často doprovázena akustickými projevy, proto i novinová zpráva o „podivném úkazu“ ve Mšicích na Znojemsku (dnes součást Oleksovic) může svědčit o sérii lokálních zemětřesení. V novinách Moravské Slovo z 22. ledna 1932 se píše: „Nevysvětlitelný dosud zjev 


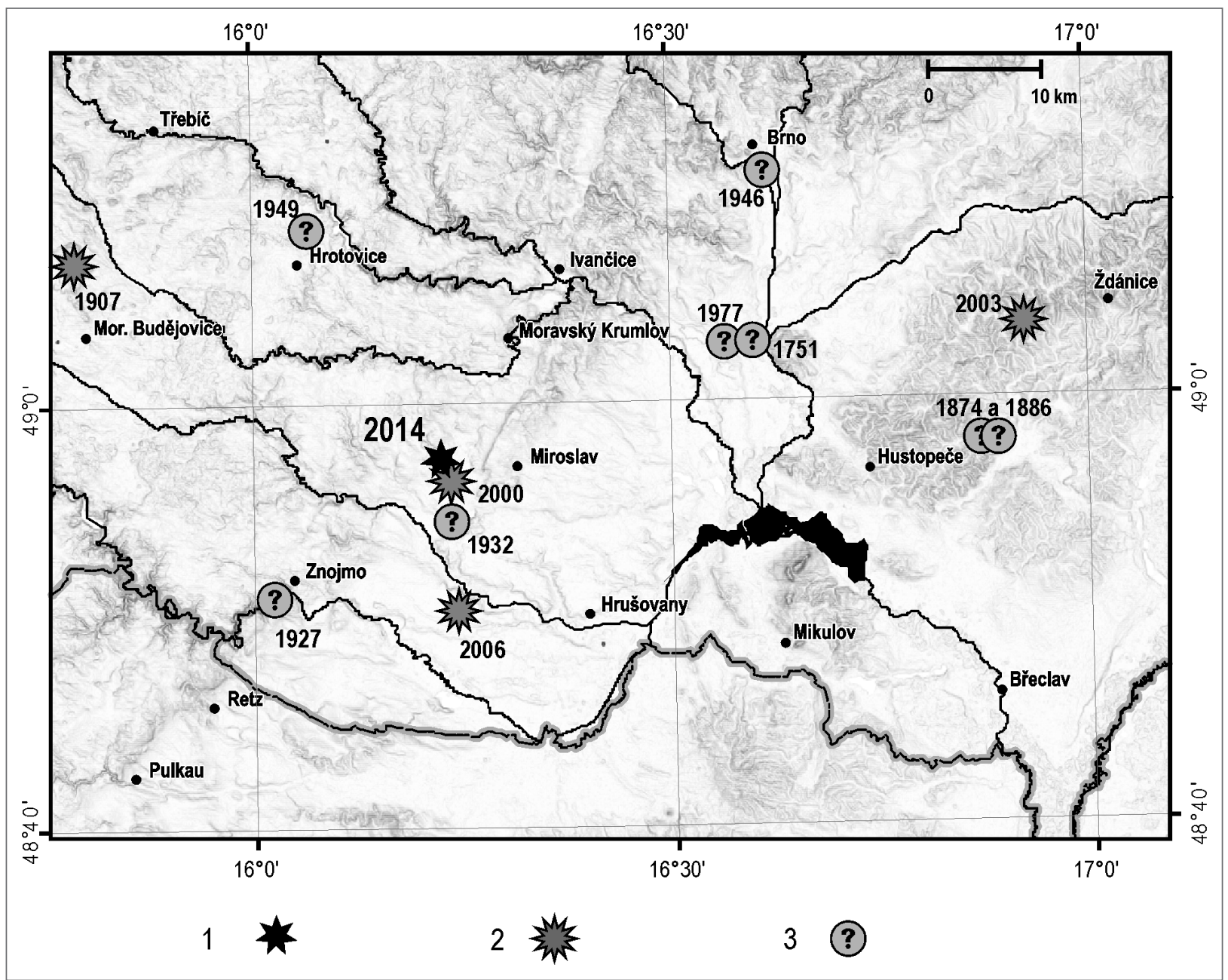

Obr. 2: Mapa epicenter zemětřesení na jižní Moravě. 1 - zemětřesení z 1. 6. 2014, 2 - zemětřesení s dobře známým ohniskem, 3 nedostatečně doložené nebo sporné zemětřesení.

Fig. 2: Epicentral map of Southern Moravia earthquakes. 1 - earthquake on June 1, 2014, 2 - well known earthquake, 3 - questionable earthquake.

je již delši dobu pozorován v obci Mšicích na Znojemsku. $S$ počátku byli občas poděšení obyvatelé domku rolníka Eggerta temným podzemním duněním. Čím dále tím častěji se dunění opakovalo a pribývalo mu na síle tak, že i okna se jím rozřinčela. Toto podzemní dunèní podobající se zvuku vzdálené bouře, trvá nyní již až pưl minuty a opakuje se velmi často."

Možné lokální zemětřesení v Hrušovanech 21. 3. 1977 uvádí Kárník et al. (1984), podle tohoto zdroje však není jasné, o které Hrušovany se jedná. V archivu GFÚ bylo dohledáno makroseismické hlášení z Hrušovan u Brna: „Dne 21. 3. 1977 zhruba v 21.17 po dobu asi 15-20 sekund silně drnčela skla v mé knihovně. Televizní stanice Vídeň potvrdila př́istí den slabé zemètřesení na jižní Moravě. “Další zprávy o tomto jevu nebyly dosud nalezeny, není jasné, kde přesně bylo ohnisko otřesu.

Jižně od Hostěradic mělo ohnisko zemětřesení ze 17. 8. 2000 s magnitudem 2,5. Toto zemětřesení bylo zaregistrováno pouze přístrojově, jeho lokalizace však není tak přesná jako u jevu z 1. 6. $2014 \mathrm{z}$ důvodu nedostatečného obklopení blízkými stanicemi. Otřes z roku 2000 měl pravděpodobně ohnisko v mnohem větší hloubce (cca $18 \mathrm{~km}$ ) než jev z roku 2014, čemuž kromě lokalizace nasvědčuje jak charakter signálu, tak i absence makroseismických hlášení. Asi o $10 \mathrm{~km}$ jižněji, u Božic, mělo ohnisko mikrozemětřesení z 1. 4. 2006 s magnitudem 1,4. Přístrojově byl zaregistrován také slabý otřes 24.9.2003 s magnitudem 0,7 s ohniskem u Uhřic, tento jev však mohl být indukován aktivitami Moravských naftových dolů v této oblasti.

Epicentra všech dosud známých zemětřesení s jistým nebo možným původem na jižní Moravě jsou vyznačena na obrázku 2.

\section{Závěr}

Přirozená zemětřesení na jižní Moravě jsou velmi vzácná. Zprávy o lokálních historických zemětřeseních jsou sporadické a většinou jsou značně pochybné nebo špatně doložené. Také detailní př́istrojová měření prováděná od roku 1995 zaznamenala jen minimální seismickou aktivitu. Zatímco na severní Moravě a ve Slezsku bylo za posledních 18 let zaregistrováno více než 3000 mikrozemětřesení, série čtyř otřesů s ohniskem u Hostěradic v červnu 2014 byla za stejné období teprve čtvrtým případem př́strojově registrovaných zemětřesení $\mathrm{v}$ prostoru jižně od Brna. Jižní Morava tak patří k seismicky nejméně aktivním regionům ČR. 
První výskyt makroseismicky pozorovaného a současně př́strojově zaznamenaného a velmi dobře lokalizovaného zemětřesení je důležitým příspěvkem $\mathrm{k}$ lepšímu poznání recentní seismické aktivity systému zlomů na jv. okraji Českého masivu.

\section{Poděkování}

Autoři děkujíJE Dukovany za možnost prezentovat výsledky monitorování seismicity a revize historických zemètresení. Provoz seismických stanic ve sledované oblasti byl dále finančně podpořen výzkumnými projekty CzechGeo-EPOS, Grant LM2010008, GAČR P210/12/0573 a OPVK 2. 3. CZ.1.07/2.3.00/20.0052.

\section{Literatura}

Hammerl, Ch. - Lenhardt, W. A. (2013): Erdbeben in Niederösterreich von 1000 bis 2009 n. Ch. - Abhandlungen der Geologischen Bundesanstalt, 67, 297 str., Wien.

Jaroš, J. - Malý, L. (2001): Boskovická brázda. - In: Pešek, J. (ed.) et al.: Geologie a ložiska svrchnopaleozoických limnických pánví České republiky. - Český geologický ústav, Praha, 243 str.

Kárník, V. - Michal, E. - Molnár, A. (1958): Erdbebenkatalog der Tschechoslovakei bis zum Jahre 1956. - Travaux. Inst. Géophys. Acad.Tchécosl. Sci. No 69, Geofysikální sborník 1957, 411-596, Praha.

Kárník, V. - Procházková, D. - Brouček, I. (1984): Catalogue of earthquakes for the territory of Czechoslovakia for the period 1957-1980. - Travaux Géophysiques XXIX (1981), No. 555, 155-186, Praha.

Michal, E. (1959): Zemětřesení na Vysočině. - Vlastivědný sborník Vysočiny. - Oddíl věd přírodních, 1959, III. díl, str. 5-30, Jihlava. Moravské Slovo. Deník, 22. ledna 1932, str. 6. František Langr, Brno.

Rzehak, A. (1909): Erdbeben in Mähren und Schlesien. - In: Allgemeiner Bericht und Chronik der im Jahre 1907 in Österreich beobachteten Erdbeben. - K. K. Zentralanstalt für Meteorologie und Geodynamik, No. IV, Wien.

Schram, W. (1901): Ein Buch für jeden Brünner: Quellenmässige Beiträge zur Geschichte unserer Stadt. - Brno: Verlag des Verfasses, 194 str.

Vrbka, A. (1902): Chronik der Stadt Znaim. - Znaim: Znaimer Landlehrerverein, 144 str. 